\title{
STRATEGI KOMUNIKASI PROGRAM KBKM 2021 DALAM UPAYA PEMAJUAN KEBUDAYAAN OLEH KEMDIKBUD-RISTEK
}

\author{
Septi Fridayani $\mathbf{P}^{\mathbf{1}}$ \\ Universitas AMIKOM Yogyakarta
}

\begin{abstract}
One of the causes of the lack of cultural existence today is not because the level of awareness of the younger generation for culture is low or irrelevant, but because of the low level of communication between generations. The purpose of this study was to find out the communication strategy of the KBKM program in an effort to promote culture by KEMDIBUD-RISTEK RI to the younger generation. This research uses descriptive qualitative method with sample determination using purposive sampling technique and case study approach. Data collection techniques using interview and observation study methods and documentation using data validity triangulation techniques. The results of this study indicate that KEMDIKBUD-RISTEK RI has made efforts to promote culture through villages by attracting the role of young people using communication strategies from Onong Uchjana Effendy in the form of planning, management and implementation of communication. The planning includes the timeline and the publication process, communication management includes redundancy (repetition), canalizing, informative, persuasive, educative and also coercive. Then carry out the analysis of issues and the role of communication, selecting targets, determining targets, developing strategies and selecting partners, determining messages, determining communication tools, managing communication and conducting partner directions, planning activities, communication budgets, as well as monitoring and evaluation.
\end{abstract}

Keywords : Communication Strategy, KBKM, Cultural Advancement

\begin{abstract}
Abstrak
Salah satu penyebab kurang eksistensinya kebudayaan saat ini bukan karena tingkat kepedulian generasi muda akan kebudayaan yang rendah atau tidak relevan, tetapi karena rendahnya komunikasi antar generasi. Tujuan penelitian ini adalah untuk mengetahui bagaimana strategi komunikasi program KBKM dalam upaya pemajuan kebudayaan oleh KEMDIBUD RISTEK kepada generasi muda. Penelitian ini mengunakan metode kualitatif deskriptif dengan penentuan sampel menggunakan teknik purposive sampling dan pendekatan studi kasus. Teknik pengumpulan data menggunakan metode studi wawancara dan observasi serta dokumentasi menggunakan teknik keabsahan data triangulasi. Hasil penelitian ini menunjukan bahwa KEMDIBUD-RISTEK RI telah melakukan upaya pemajuan kebudayaan melalui desa dengan menarik peran kaum muda menggunakan strategi komunikasi dari Onong Uchjana Effendy berupa perencanaan, manajemen dan pelaksanaan komunikasi. Perencanaan yang dilakukan meliputi timeline dan proses publikasi, manajemen komunikasi meliputi redundancy (repetition), canalizing, informatif, persuasif, edukatif dan juga koersif. Kemudian pelaksanaan analisis isu dan peran
\end{abstract}

\footnotetext{
${ }^{1}$ septi.p@students.amikom.ac.id
} 
komunikasi, pemilihan target, menentukan target, mengembangkan strategi dan memilih partner, menentukan pesan, menentukan alat komunikasi, mengatur komunikasi dan melakukan pengarahan partner, perencanaan aktifitas, anggaran komunikasi, serta pengawasan dan evaluasi.

Kata Kunci : Strategi Komunikasi, KBKM, Pemajuan Kebudayaan

\section{Pendahuluan}

Pemberlakuan kebijakan untuk melakukan pembatasan sosial pada masa pandemi berpengaruh besar terhadap berbagai sektor yang berhubungan dengan mobilitas masyarakat. Salah satu sektor yang terkena dampak besar bukan hanya pada bidang kesehatan dan bidang ekonomi saja, pelaku seni dan budaya juga merasakan dampak seperti kurang memiliki kebebasan berekspresi dan kehilangan mata pencaharian sehingga yang dikhawatirkan dapat menyebabkan peralihan profesi dan cultural lost dalam menghadapi dampak pandemi.

Dalam upaya pemajuan kebudayaan, Kementerian Pendidikan, Kebudayaan, Riset, dan Teknologi Republik Indonesia (KEMDIKBUD RISTEK RI) pada tanggal 10 Oktober 2019 meluncurkan Indeks Pembangunan Kebudayaan atau yang kerap disebut IPK pada rangkaian kegiatan program Pekan Kebudayaan Nasional (PKN). Terdapat unsur-unsur pemajuan kebudayaan, sepuluh objek pemajuan kebudayaan (OPK), serta ekosistem kebudayaan dan pengarusutamaan kebudayaan dari hulu ke hilir berdasarkan pada Undang-undang Nomor 5 Tahun 2017 tentang Pemajuan Kebudayaan,.

IPK menjadi instrumen yang dapat mengukur pencapaian pembangunan kebudayaan yang berada pada tingkat nasional dan juga daerah. IPK ini disusun oleh Kemendikbud bersama dengan beberapa instansi pemerintah seperti Kementerian Perencanaan Pembangunan Nasional (PPN)/Badan Perencanaan Pembangunan Nasional (Bappenas), dan Badan Pusat Statistik (BPS). Hal ini membuat Indonesia menjadi negara pertama di dunia yang memiliki indeks pengukuran yang secara spesifik dapat dijadikan pengukur capaian pembangunan kebudayaan. Dalam mengukur IPK, terdapat beberapa aspek yang harus di nilai seperti warisan budaya, ketahanan sosial budaya, pendidikan, ekonomi budaya, gender, budaya literasi, dan juga ekspresi budaya (jendela.kemdikbud.go.id). 
Badan Pusat Statistik dengan menggunakan data pada tahun 2018 telah merilis nilai IPK nasional sebesar 53,74. Adapun indikator yang mendapatkan skor tertinggi terdapat pada dimensi Ketahanan Sosial Budaya dengan indeks sebesar 72,84. Selanjutnya dari dimensi Pendidikan mendapatkan sebesar 69,67. Sementara itu Dimensi Ekonomi Budaya mendapatkan skor terendah dengan nilai indeks sebesar 30,55. Kemudian terdapat 13 provinsi yang memiliki nilai IPK di atas angka nasional.

\begin{tabular}{|l|c|l|l|}
\hline \multicolumn{1}{|c|}{ Nama Provinsi } & IPK & \multicolumn{1}{|c|}{ Nama Provinsi } & \multicolumn{1}{c|}{ IPK } \\
\hline Daerah Istimewa Yogyakarta & 73,79 & Jawa Timur & 56,66 \\
\hline Bali & 65,39 & Sulawesi Utara & 56,02 \\
\hline Jawa Tengah & 60,05 & DKI Jakarta & 54,67 \\
\hline Bengkulu & 59,95 & Bangka Belitung & 54,37 \\
\hline Nusa Tenggara Barat & 59,92 & Lampung & 54,33 \\
\hline Kepulaua Riau & 58,83 & Kalimantan Selatan & 53,79 \\
\hline Riau & 57,47 & & \\
\hline
\end{tabular}

Tabel 1. Capaian Indeks Pemajuan Kebudayaan

Sumber : Badan Pusat Statistik Indonesia, 2019

Kementerian Pendidikan, Kebudayaan, Riset, dan Teknologi Republik Indonesia (KEMDIKBUD RISTEK RI) melalui Direktorat Jenderal Kebudayaan menggelar berbagai program bertajuk pemajuan kebudayaan yang juga berpedoman kepada Undang-undang Pemajuan Kebudayaan No. 5 Tahun 2017. Salah satunya pada Direktorat Pembinaan Tenaga dan Lembaga Kebudayaan (PLTK), yang menjadi penanggungjawab program Kemah Budaya Kaum Muda (KBKM).

Dalam perkembangan teknologi dan upaya pemajuan kebudayaan, kurang eksistensinya kebudayaan saat ini bukan karena tingkat kepedulian kaum muda yang rendah atau tidak relevan dengan jaman, akan tetapi penyebabnya adalah rendahnya komunikasi antar generasi, hal ini disampaikan oleh Cyntia Handy dalam proses inkubasi regional program KBKM 2021. 
KBKM sendiri merupakan sebuah ajang kompetisi yang mengumpulkan bakat-bakat imajinatif dan kreatif kaum muda untuk menjawab tantangan pemajuan kebudayaan melalui pendekatan STEAM (Science, Technology, Engineering, Arts, Mathematics) dan atau Revolusi Industri 4.0 yang akan diinkubasi sebelum seleksi selama satu bulan. KBKM sudah berjalan selama tiga tahun yang di mulai pada tahun 2019. Program ini bertujuan untuk mencari inisiatif kaum muda dalam pemajuan kebudayaan agar Indonesia siap menghadapi tantangan masa depan. Hasil karya yang pada tahun 2021 ini berupa purwarupa dan aplikasi yang bukan produk jadi (prototype) yang kemudian akan di launching setelah adanya proses inkubasi lanjutan setelah lolos menuju nasional (kbkm.kebudayaan.id).

KBKM menggunakan pedoman utama yaitu sepuluh objek pemajuan kebudayaan yang sangat berpotensi untuk dikembangkan seperti tradisi lisan, manuskrip, adat istiadat, ritus, pengetahuan tradisional, teknologi tradisional, seni, bahasa, permainan rakyat, dan olahraga tradisional. Program ini difokuskan kepada upaya untuk dapat menumbuhkan semangat berkolaborasi dan peran kaum muda dalam upaya pemajuan kebudayaan dengan beragam latar belakang pendidikan dan kebudayaan. Sehingga program KBKM 2021 ini menjadi salah satu strategi dalam upaya pemajuan kebudayaan yang dapat menjadi jembatan komunikasi antar generasi.

Teknologi memang menjadi salah satu penggerak utama pada berbagai sektor dalam kehidupan terutama kebudayaan, akan tetapi konten dapat menjadi kunci utama dalam memenangkan persaingan yang ada di global. Oleh karena itu, diperlukan strategi komunikasi untuk menarik perhatian kaum muda dalam upaya pemajuan kebudayaan untuk mengikuti program KBKM 2021. Strategi Komunikasi ini dapat menggabungkan beberapa unsur seperti Rencana Komunikasi (communication planning) dan Manajemen Komunikasi (communication management) untuk dapat mencapai tujuan tersebut. Strategi komunikasi ini harus dapat menunjukkan cara kerjanya dalam arti bahwa pendekatannya dapat berubah sewaktu-waktu tergantung pada keadaan dan kondisi (Effendy, 2009:31) 
Pentingnya strategi komunikasi yang dibentuk dan diproses dengan matang, dapat menjadi kunci suksesnya sebuah program. Berdasarkan latar belakang tersebut, peneliti tertarik untuk melakukan penelitian terhadap bagaimana proses strategi komunikasi pada program KBKM 2021 dalam upaya pemajuan kebudayaan oleh Kemdikbud-ristek kepada kaum muda yang berupa perencanaan komunikasi dan manajemen komunikasi.

Alasan peneliti mengambil judul "Strategi Komunikasi Program KBKM 2021 dalam Upaya Pemajuan Kebudayaan oleh KEMDIKBUD RISTEK" karena program KBKM dinilai dapat menjadi salah satu program kolaborasi kaum muda yang inklusif dari berbagai latar belakang pendidikan dan komunikasi antar generasi dalam mewujudkan ide imajinatif untuk meningkatan Indeks Pembangunan Kebudayan dalam upaya pemajuan kebudayaan di Indonesia.

\section{Metode Penelitian}

Penelitian ini dilakukan pada bulan Sepetember-Nopember, dengan jenis penelitian yang digunakan peneliti pada "Strategi Komunikasi Program Kbkm 2021 dalam Upaya Pemajuan Kebudayaan oleh Kemdikbud-Ristek" adalah penelitian kualitatif dengan pendekatan deskriptif.

Dengan penelitian kualitatif, dasar pemikiran dilakukan oleh peneliti untuk menafsirkan sebuah fenomena yang telah terjadi, penelitian kualitatif berlandaskan pada dasar pemikiran yang digunakan untuk melakukan penelitian pada kondisi objek alamiah yang berlawanan dengan proses eksperimen atau layaknya penelitian sains. Penelitian kualitatif ini merupakan penelitian yang menekankan pada pemahaman mengenai masalah-masalah dalam kehidupan sosial berdasarkan kondisi nyata atau natural setting yang komprehensif (Aggito 2018: 9).

Peneliti menggunakan desain penelitian deskriptif yang menggambarkan tentang suatu gejala sosial dengan tujuan untuk menggambarkan sifat sesuatu yang sedang berlangsung. Dalam penelitian ini, peneliti perlu terjun ke lapangan untuk mengkaji secara dalam sehingga metode penelitian kualitatif deskriptif tepat untuk penelitian ini. kemudian peneliti menggunakan paradigma 
konstruktivisme. Metode penelitian yang tepat digunakan oleh peneliti adalah studi kasus, dimana metode ini menggunakan berbagai sumber data yang dapat digunakan untuk melakukan riset, menguraikan, dan menjelaskan secara meluas mengenai individu, suatu program, kelompok, organisasi atau peristiwa secara sistematis

Obyek penelitian ini adalah Program Kemah Budaya Kaum Muda tahun 2021. Kemudian informan penelitian ditentukan dengan teknik purposev sampling, yakni mencakup orang-orang yang di seleksi atas dasar kriteria tertentu dengan berbagai pertimbangan tertentu (Sugiyono, 2011). Informan yang terdapat pada penelitian ini yaitu penanggungjawab program KBKM 2021, inisiator dan panitia penyelenggara program KBKM 2021, mentor dan pemateri KBKM 2021, serta peserta KBKM 2021 yang masuk tahap regional hingga nasional.

Teknik pengumpulan data yang digunakan dalam penelitian ini adalah observasi, wawancara, dan juga dokumentasi. Teknik analisis data yang digunakan peneliti yaitu Reduksi Data, Data Display serta Penarikan Kesimpulan. Selanjutnya dalam teknik uji keabsahan data peneliti menggunakan Teknik Triangulasi untuk mendapatkan sumber data yang sama dari beberapa teknik pengumpulan data. Teknik penyajian data yang digunakan dalam penelitian ini adalah teknik penyajian data deksriptif dimana penulis menganalisis serta memaparkan hasil penelitiannya berdasarkan fakta yang didapatkan dilapangan.

\section{Hasil dan Pembahasan}

Menurut Onong Uchjana Effendy (dalam Suryadi, 2018: 5) perpaduan dari perencanaan komunikasi dan manajemen komunikasi merupakan startegi komunikasi yang tepat untuk mencapai suatu tujuan, oleh sebab itu operasional secara taktis harus diterapkan dengan pedekatan (appoach) yang situasional. Selanjutnya terdapat dua aspek dalam stratgei komunikasi yang harus dipahami, yaitu strategi yang dimaknai secara mikro (single communication medium strategy) dan secara makro (planned multimedia strategy). Kedua aspek tersebut 
memiliki fungsi ganda seperti menyebarluaskan pesan yang terdapat dalam komunikasi yang bersifat informatif dan menjembatani culture gap.

Strategi komunikasi berkaitan erat antara tujuan yang ingin dicapai dengan konsekuensi atau masalah-masalah yang perlu diperhitungkan. Strategi komunikasi memiliki beberapa metode menurut teknik pelaksanaanya, menurut Fajar (dalam Widyanti, 2018: 6) teknik pelaksanaan strategi komunikasi dapat diwujudkan dalam dua bentuk, yaitu redundancy (repetition) dan Canalizing. Sedangkan yang kedua menurut isinya seperti: informatif, persuasif, edukatif dan juga koersif.

Selanjutnya Onong Uchjana Effendy (dalam Wardiman, 2020: 231) berpendapat bahwa tahapan dalam melaksanakan strategi komunikasi yang efektif meliputi beberapa hal seperti analisis isu dan peran komunikasi, pemilihan target, menentukan target, mengembangkan strategi dan memilih partner, menentukan pesan, menentukan alat komunikasi, mengatur komunikasi dan melakukan pengarahan partner, perencanaan aktifitas, anggaran komunikasi, serta pengawasan dan evaluasi.

Program Kemah Budaya Kaum Muda (KBKM) merupakan salah satu program swadaya dari KEMDIKBUD RISTEK melalui Ditjen Kebudayaan Direktorat Pembinaan Tenaga dan Lembaga Kebudayaan (PLTK). Setelah melakukan pengumpulan data yang dilakukan melalui wawancara, observasi dan dokumentasi, peneliti mendapatkan informasi mengenai penerapan strategi yang dilakukan pada program KBKM 2021 berupa perencanaan dan manajemen komunikasi. Adapun kompetisi dan inkubasi sebagai salah satu komponen untuk menarik generasi muda berpartisipasi dalam memajuan kebudayaan.

Menurut Bobby Fernandes yang merupakan kordinator KBKM 2021 mengatakan KBKM merupakan sebuah platform yang memiliki tujuan untuk menarik anak muda ikut dalam kerja pemajuan kebudayaan.

"Selama ini kerja pemajuan kebudayaan selalu identik dengan orang tua, seniman, dan jauh dari anak muda yang latar belakangnya non kebudayaan seperti anak teknik dan jauh dari 
anak-anak muda yang berlatar belakang non kebudayaan lainnya, silakan teman-teman anak teknik, anak sosial dan lain-lainnya mengartikannya seperti apa. Kebudayaan sendiri punya arti yang luas yaitu kebudayaan bukan hanya seni walaupun seni masuk di dalamnya, tetapi kebudayaan itu adalah semua bentuk hasil dari tingkah laku dari akal budi manusia dan juga hasil dari komunikasi manusia itu sendiri adalah kebudayaan dan itu spektrumnya sangat luas" (hasil wawancara pada 5 Oktober 2021).

Dari hasil penelitian, terdapat beberapa strategi komunikasi yang diterapkan pada program KBKM 2021, strategi ini bertujuan untuk menumbuhkan semangat berkolaborasi dan peran kaum muda dalam upaya pemajuan kebudayaan. Menurut Effendy (dalam Nayiroh, 2020: 18) untuk dapat mencapai tujuan tersebut tentunya strategi tidak hanya berfungsi sebagai peta jalan yang sekedar menunjukkan arah saja, melainkan harus menunjukkan taktik operasionalnya.

\section{a. Perencanaan Komunikasi Program KBKM 2021}

\section{TAHAPAN KBKM 2021}
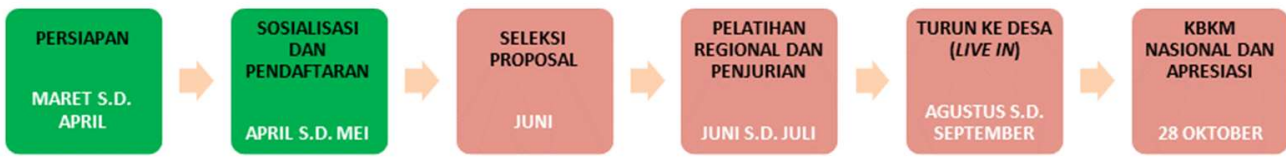

Gambar 1. Tahapan Program KBKM 2021

Sumber: Direktorat Pembinaan Tenaga dan Lembaga Kebudayaan, 2021

Dalam proses perencanaan program KBKM 2021 dilakukan pembuatan tahapan atau timeline kegiatan program selama 1 periode, mulai dari tahap persiapan hingga tahap apresiasi nasional. Pada program KBKM ditahun ini mengalami perubahan objek yang lebih spesifik ke desa. 


\section{TAHAPAN PUBLIKASI KBKM 2021}
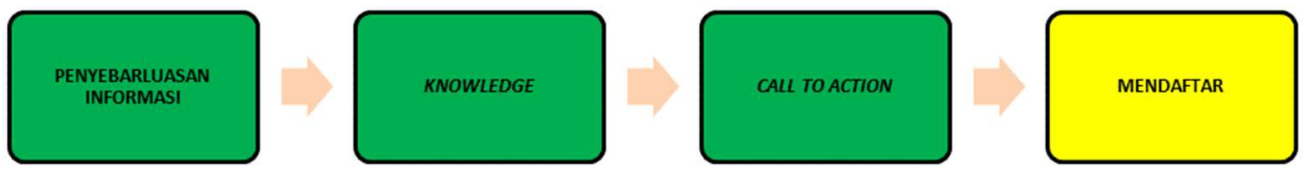

Gambar 2. Tahapan Publikasi Program KBKM 2021

Sumber: Direktorat Pembinaan Tenaga dan Lembaga Kebudayaan, 2021

Sebagai upaya mempublikasikan dan menjaring peserta KBKM 2021, dilakukan beberapa langkah seperti mengembangkan website KBKM, melakukan publikasi melalui media sosial yaitu instagram dan facebook, bekerjasama dengan beberapa public figure yang memiliki kesamaan demografi dengan KBKM 2021, baik melalui instastory, live Instagram, maupun instafeed. Kemudian bekerjasama dengan beberapa akun microbuzzer yang memiliki kesamaan demografi dengan sasaran KBKM 2021, membuat lima konten video motion tentang KBKM 2021 dan juga membuat konten podcast dalam empat episode dengan menghadirkan narasumber yang relevan dengan tema-tema pada program KBKM 2021.

Selanjutnya program ini juga melakukan pengiriman email blast ke 7.000 data komunitas kebudayaan, melaksanakan webinar yang dilakukan oleh UPT untuk menyebarluaskan informasi terkait KBKM 2021 ke jaringan masing-masing UPT, membuat grup di telegram yang dapat memudahkan calon peserta untuk melakukan tanya jawab seputar KBKM 2021, kemudian melakasanakan webinar dengan calon peserta KBKM 2021, bekerjasama dengan beberapa pihak seperti Ditjen Dikti, BPPT, BRI Ventures, Haloryan, dan lain sebagainya.

\section{b. Manajemen Komunikasi Program KBKM 2021}

Menurut Berto Tukan yang merupakan perumus awal KBKM, mengatakan bahwa strategi komunikasi yang dilakukan di tahun 2021 merupakan hasil evaluasi dari startegi tahun sebelumnya, media yang digunakan masih sama yaitu YouTube, grup Facebook, Instagram, dan Website. 
"Ada hal yang berbeda dengan tahun lalu, karena tahun lalu strategi yang digunakan kurang stabil. Hanya dari segi kontennya yang berbeda, untuk kanal yang digunakan masih sama. Kalau tahun ini kita menambah podcast, webseries dan vlog untuk menjadi strategi komunikasi yang baru. Tahun lalu diskusi di IG live itu sangat jarang dilakukan, tentang seperti apa itu $\mathrm{kbkm}$ dan bagaimana stepnya, apa itu KBKM, nah ditahun ini kita buat sesering mungkin" (wawancara pada 8 Oktober 2021)

Dengan adanya manajemen komunikasi yang baik, terdapat teknik pelaksanaan strategi komunikasi yang dapat diwujudkan dalam dua bentuk, yaitu redundancy (repetition) dan Canalizing. Sedangkan yang kedua menurut isinya seperti: informatif, persuasif, edukatif dan juga koersif.

Bentuk pertama yaitu redundancy atau repetition yang digunakan program KBKM tahun 2021, banyak ditemui melalui sosial media yaitu Instagram, dari hasil wawancara bersama Hirlan Maulana yang merupakan peserta regional 3 program KBKM ini, ia mengatakan informasi yang ditemuinya awal mula melalui instagram, saat itu ia melihat adanya postingan mengenai live instagram kemah budaya yang diadakan beberapa kali, selanjutnya ia mencoba untuk mengikuti acara tersebut dan pada akhirnya membuatnya tertarik setelah memahami program ini. Dengan adanya teknik mengulang pesan yang berisikan informasi jelas mengenai program, dapat mempengaruhi keputusun khalayak.

Selanjutnya adalah teknik Canalizing yang merupakan teknik untuk memahami dan meneliti pengaruh sebuah kelompok terhadap individu atau khalayak. Mikhael Saor P. Lumban Gaol salah satu peserta dari regional 1 yang lolos tahap nasional mengatakan bahwa informasi yang ia dapatkan mengenai program KBKM ini melalui komunitasnya yaitu Komunitas Peduli Museum dan Sejarah (Kopi Murah) dan informasi mendalam yang ia dapatkan melalui Instagram dan Website. 
"Sebenarnya yang menjadi ketetarikan dan semangatnya itu yang Pak Dirjen katakan, kalau orang kebudayaan mau membahas atau berbicara kebudayaan atau melakukan aksi-aksi kebudayaan itu sudah biasa, tetapi ketika orang dari latar belakang berbeda berbicara dan mau bergerakan dibidang kebudayaan itu baru luar biasa. Jadi kebetulan tiga-tiganya yang dari tim saya latar belakangnya jauh dari budaya" (wawancara pada 12 Nopember 2021)

Hal ini membuktikan adanya pengaruh sebuah kelompok untuk menarik dan mempengaruhi khalayak untuk mengikuti sebuah kegiatan. Program KBKM juga mengadirkan beberapa Key Opinion Leader (KOL) yang memiliki kesamaan demografi dengan KBKM 2021.

Selain konten melalui instagram, KBKM juga menampilkan berbagai konten yang bersifat informatif, persuasif, edukatif dan juga koersif yang disajikan melalui channel YouTube. Koten tersebut meliputi kategori kompetisi, cara melakukan pendaftaran dan sarana untuk mengenalkan misi KBKM untuk memantik anak-anak memilik attention.

\section{VIDEO PUBLIKASI DAN PODCAST}

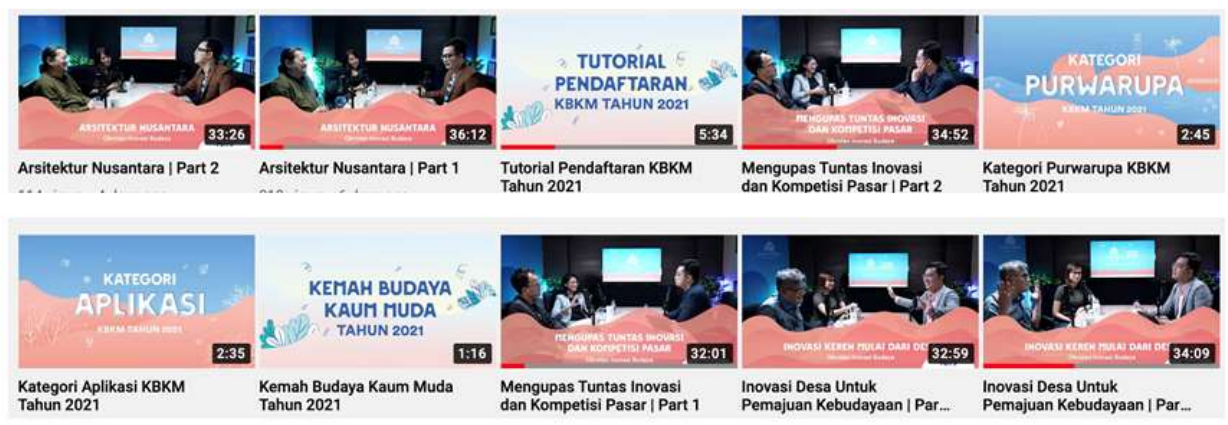

Gambar 3. Publikasi konten Video di YouTube

Sumber: Direktorat Pembinaan Tenaga dan Lembaga Kebudayaan, 2021 


\section{c. Pelaksanaan Program KBKM 2021}

Berdasarkan teori dari Onong Uchjana Effendy pada bukunya berjudul Ilmu Komunikasi: Teori dan Praktek, untuk melaksanakan strategi komunikasi yang efektif terdapat beberapa tahapan yang perlu ada dalam sebuah program. Tahapan tersebut juga terdapat pada program KBKM 2021 yang menjadi indikator keberhasilan program.

Tahapan yang pertama adalah analisis isu dan peran komunikasi, dalam hal ini program KBKM 2021 mengambil tema "Inovasi Desa untuk Pemajuan Kebudayaan”. Dimasa pandemi ini desa menjadi salah satu sasaran peningkatan ekonomi oleh pemerintah, berdasarkan hal tersebut, KBKM mendorong kaum muda untuk dapat menggali potensi kebudayaan khususnya yang ada di desa. Selanjutnya pembangunan desa berbasis pada Kebudayaan dalam bentuk perencanaan kemudian melindungi serta dapat mengembangkan nilai ekspresi juga praktik kebudayaan lokal.

KBKM di tahun 2021 sadar bahwa praktik-praktik kebudayaan tersebut tidak hanya dapat dilakukan melalui studi literatur, sehingga terdapat perancangan tahapan untuk turun ke desa atau residensi bagi para peserta program ini, hal ini untuk menunjang dan menyempurnakan inisiatif yang mereka akan laksanakan. Harapannya ide imajinatif dan kreatif yang diciptakan oleh kaum muda tepat guna serta dapat teraplikasikan dalam kehidupan sehari-hari.

Berdasarkan hasil observasi, pemilihan target dan menentukan target untuk pelaksanaan KBKM 2021 juga mengedepankan kesetaraan gender dengan mensyaratkan peserta harus memiliki 2-3 perempuan pada kategori aplikasi yang maksimal peserta dalam tim 5 orang, dan 1-2 perempuan pada kategori purwarupa yang maksimal peserta dalam tim berjumlah 3 orang dengan usia 18-25 tahun. Selain itu di tahun 2021 program ini juga menargetkan aksesibilitas penyandang disabilitas untuk dapat ikut serta dengan penyediaan akses Bahasa Isyarat Indonesia (Bisindo) untuk dapat mewujudkan KBKM inklusif. 


\begin{tabular}{|c|c|c|c|c|c|c|c|c|c|c|c|c|c|}
\hline \multicolumn{14}{|c|}{ Ringkasan Peserta Tingkat Regional 2021} \\
\hline \multirow{2}{*}{ No } & \multirow{2}{*}{ Regional } & \multirow{2}{*}{\multicolumn{4}{|c|}{ Jumlah }} & \multicolumn{8}{|c|}{ Kategori } \\
\hline & & & & & & \multicolumn{4}{|c|}{ Aplikasi } & \multicolumn{4}{|c|}{ Prakarya } \\
\hline 1 & 1 & 61 & Kelompok & 255 & Orang & 36 & Kelompok & 180 & Orang & 25 & Kelompok & 75 & Orang \\
\hline 2 & II & 73 & Kelompok & 301 & Orang & 41 & Kelompok & 205 & Orang & 32 & Kelompok & 96 & Orang \\
\hline 3 & III & 64 & Kelompok & 252 & Orang & 30 & Kelompok & 150 & Orang & 34 & Kelompok & 102 & Orang \\
\hline 4 & IV & 61 & Kelompok & 245 & Orang & 31 & Kelompok & 155 & Orang & 30 & Kelompok & 90 & Orang \\
\hline 5 & $\mathrm{~V}$ & 66 & Kelompok & 270 & Orang & 36 & Kelompok & 180 & Orang & 30 & Kelompok & 90 & Orang \\
\hline 6 & VI & 56 & Kelompok & 214 & Orang & 23 & Kelompok & 115 & Orang & 33 & Kelompok & 99 & Orang \\
\hline 7 & VII & 41 & Kelompok & 153 & Orang & 15 & Kelompok & 75 & Orang & 26 & Kelompok & 78 & Orang \\
\hline & & 422 & Kelompok & 1690 & Orang & 212 & Kelompok & 1060 & Orang & 210 & Kelompok & 630 & Orang \\
\hline
\end{tabular}

Gambar 4. Ringkasan Peserta KBKM 2021 Tingkat Regional

Sumber: Direktorat Pembinaan Tenaga dan Lembaga Kebudayaan, 2021

Dari hasil data tersebut, perubahan tema KBKM menjadi "Inovasi Desa untuk Pemajuan Kebudayaan" yang dilakukan di tahun 2021 ini mengalami penurunan jumlah pendaftar dari tahun sebelumnya yang mencapai 517 kelompok. Hal ini dapat tolak ukur keberhasilan strategi komunikasi program KBKM dalam menarik minat kaum muda. Meskipun terdapat penurunan jumlah pendaftar, namun program ini berhasil menjadi stimulus menarik peran kaum muda untuk memberikan inovasi pemajuan kebudayaan di desa.

Kaum muda Indonesia memiliki potensi yang dapat mempercepat proses pemajuan kebudayaan Indonesia. Oleh karena itu, Boby Fernandes selaku kordinator KBKM 2021 juga mengatakan bahwa kaum muda sebenarnya bukan tidak ingin berperan namun lebih tepatnya belum begitu kenal dan belum mengetahui kira-kira peran apa yang bisa diambil dalam kerja-kerja kebudayaan. Hal ini juga dipaparkan oleh Cyntia Handy yang merupakan pemateri sekaligus mentor nasional pada program KBKM 2021

"KBKM ini merupkan langkah awal atau stimulus pemerintah untuk mentriger, ketika sudah banyak yang mulai tertarik, banyak yang mengerti tentang kebudayaan nahh baru pemerintah mampu menciptakan (wadah pemajuan kebuadayaan)". Wawancara pada 14 Nopember 2021.

Selanjutnya, pesan yang ingin disampaikan pada program ini 
menurut Boby Fernandes selaku kordinator program KBKM 2021 kepada kaum muda adalah kebudayaan sendiri dapat dilihat sebagai sebuah arena bermain yang menyenangkan, kaum muda dapat mengeksplor apapun tentang kebudayaan ke bidang maupun latar belakang ilmu masing-masing.

"Berbicara tentang pemajuan kebudayaan, saya sampaikan kepada mereka bahwa kita tidak mengajak mereka untuk menjadi penari, pedalang. Yang saat ini dibutuhkan adalah bagaimana kebudayaan itu selalu ada dan dibicarakan dalam setiap ritme kehidupan kita sehari-hari, dalam berpakaian, dalam bertingkah laku, dalam berteknologi, dan juga dalam bisnis seperti itu." Wawancara bersama Cyntia Handy pada 14 Nopember 2021.

Dari segi media, kebudayaan dimasa pandemi saat ini memasuki era digital, sehingga program KBKM 2021 lebih banyak komunikasi melalui digital platform seperti media sosial, melalui seminar online atau webinar, melalui bahan-bahan publikasi online, digital pamflet dan lainlain. Untuk media yang paling yang paling masif yaitu lewat Instagram dan YouTube yang menjadi sarana publikasi memperkenalkan misi KBKM untuk memantik kaum muda memilik attention sehingga KBKM sendiri pendekatannya melalui teknologi 4.0.

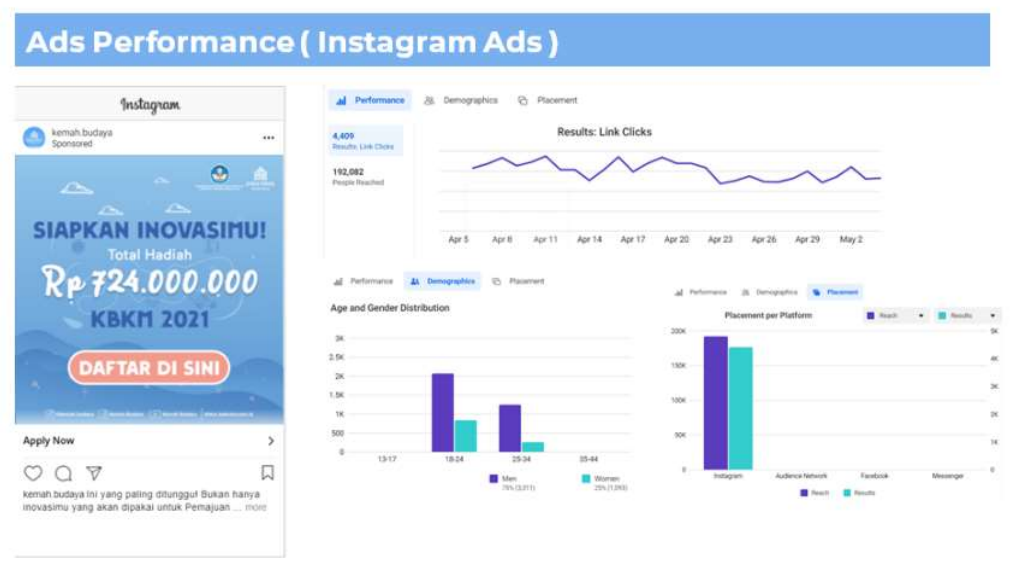

Gambar 5. Ads Performance Instagram

Sumber: Direktorat Pembinaan Tenaga dan Lembaga Kebudayaan, 2021 
Selanjutnya adalah pengawasan dan evaluasi, berdasarkan hasil observasi melalui media yang digunakan untuk strategi komunikasi dan hasil wawancara kepada informan, pada tahapan ini terdapat proses komunikasi yang perlu dievaluasi kembali. Pertama adalah pelaksanaan program dengan peserta yang harus berasal dari tempat yang sama, ketika berbicara soal pemajuan kebudayaan yang bermanfaat untuk masyarakat, peserta harus sudah hadir di masyarakat dan sudah mengetahui kondisi desa sasaran atau memahami lokasi terkait. Hal ini menjadi pertimbangan ketika melakukan pemajuan kebudayaan di desa, jarak sangat menentukan seberapa cepat dan mudahnya pemajuan kebudayaan dapat dilaksanakan dan juga dapat berkelanjutan.

Kemudian terkait perencanaan program, perlu adanya pematangan konsep yang dibuat booklet yang juga berisikan indikator penilaian karya guna memudahkan peserta untuk menerima informasi secara detail, hal ini menjadi perhatian khusus peserta setelah penjurian terlaksana, perlu adanya keterbukaan dalam pelaksanaan penilaian dan informasi timeline yang jelas jika terjadi keterlambatan. Selanjutnya terkait orisinlitas ide, banyak yang menggunakan metode amati, tiru, dan modifikasi. Sehingga perlu adanya level-level orisinalitas dalam arti peserta memegang penuh dan bukan dikendalikan.

\section{Kesimpulan}

Program KBKM 2021 berhasil menjadi salah satu program inovasi pemajuan kebudayaan melalui desa yang mengedepankan peran dan kolaborasi kaum muda dari berbagai latar belakang Pendidikan dalam mewujudkan ide imajinatif untuk meningkatan pemajuan kebudayaan menggunakan STEAM. Hal ini dapat dilihat dari antusias pendaftar meskipun terdapat perubahan tema KBKM menjadi "Inovasi Desa untuk Pemajuan Kebudayaan" yang dilakukan di tahun 2021. 
Jumlah kelompok yang mendaftar tahun 2021 mengalami penurunan jumlah kelompok pendaftar di tahun sebelumnya yang mencapai 517 kelompok sedangkan tahun 2021 hanya mencapai 422 kelompok,akan tetapi penurunan yang terjadi tidak begitu signifikan. Hal ini dapat tolak ukur keberhasilan strategi komunikasi program KBKM dalam menarik minat kaum muda. Meskipun terdapat penurunan jumlah pendaftar, program ini tetap berhasil menjadi stimulus menarik peran kaum muda untuk memberikan inovasi pemajuan kebudayaan di desa.dengan terbentuknya komunitas Ikatan Alumni Kemah Budaya Kaum Muda yang diinisiasikan oleh peserta yang melakukan kolaborsi bersama untuk memberikan peran dalam pemajuan kebudayaan.

Adapun strategi komunikasi efektif yang berhasil dicapai dapat dilihat menggunakan teori dari Onong Uchjana Effendy berupa perencanaan, manajemen dan pelaksanaan komunikasi. Perencanaan yang dilakukan meliputi timeline dan proses publikasi, manajemen komunikasi meliputi redundancy (repetition), canalizing, informatif, persuasif, edukatif dan juga koersif. Selanjutnya pelaksanaan komunikasi yang efektof dapat berupa analisis isu dan peran komunikasi, pemilihan target, menentukan target, mengembangkan strategi dan memilih partner, menentukan pesan, menentukan alat komunikasi, mengatur komunikasi dan melakukan pengarahan partner, perencanaan aktifitas, anggaran komunikasi, serta pengawasan dan evaluasi. 


\section{Daftar Pustaka}

Anggito, A dan Setiawan, J. 2018. Metodologi penelitian kualitatif. Jawa Barat : CV Jejak (Jejak Publisher).

Effendy, Onong Uchjana. 2009. Ilmu Komunikasi: Teori dan Praktek. Bandung: PT Remaja Rosdakarya.

Kusuma, Y. 2021. Pentingnya Strategi Komunikasi Dalam Berkomunikasi. Jurnal Sudut Pandang, 2(5), 1-5.

Nahak, H. M. 2019. Upaya melestarikan budaya indonesia di era globalisasi. Jurnal Sosiologi Nusantara, 5(1), 65-76.

Nayiroh, L. 2020. Strategi Komunikasi Pemerintah Daerah dalam Upaya Pelestarian Budaya Sunda pada Kepemimpinan Dedi Mulyadi di Kabupaten Purwakarta. Jurnal PIKMA: Publikasi Ilmu Komunikasi Media Dan Cinema, 3(1), 14-20.

Nugraha, A. S. 2020. Kearifan Lokal dalam Menghadapi Pandemi Covid-19: Sebuah Kajian Literatur. Sosietas, 10(1), 745-753.

Panuju, R. 2018. Pengantar Studi (Ilmu) Komunikasi: Komunikasi Sebagai Kegiatan Komunikasi Sebagai Ilmu. Kencana.

Purba, B., dkk. 2020. Ilmu Komunikasi: Sebuah Pengantar. Yayasan Kita Menulis.

Romadhan, M. I. 2020. Proses komunikasi dalam pelestarian budaya saronen kepada generasi muda. Jurnal Pikom (Penelitian Komunikasi dan Pembangunan), 20(1), 1-12.

Romli, R., dan Romli, N. A. 2020. Implementasi strategi komunikasi "Bandung Juara” sebagai bagian dari city branding Kota Bandung. PRofesi Humas, 4(2), 263-289.

Rustan, A. S., dan Hakki, N. 2017. Pengantar ilmu komunikasi. Deepublish.

Sugiyono. 2011. Metode Penelitian Kuantitatif, Kualitatif Dan Kombinasi (Mixed Methods). Bandung: Alfabet.

Suryadi, Edi. 2018. Strategi Komunikasi Sebuah Analisis Teori dan Praktis di Era Global. Bandung: PT Remaja Rosdakarya

Wardiman, W., Hidayatullah, A., dan Komariah, S. 2020. Strategi Komunikasi Balai Taman Nasional Tambora dalam Pengembangan Kawasan Oi Marai Sebagai Kawasan Wisata. Jurnal Komunikasi dan Kebudayaan, 7(2), 229237.

Widyanti, Carlie Nurul. 2018. Strategi Komunikasi Place Branding (Studi Deskriptif Kualitatif Tentang Strategi Komunikasi PT.Sinergi Colomadu dalam Place Branding De Tjolomadoe Eks Pabrik Gula Colomadu Karanganyar sebagai Destinasi Wisata untuk Menarik Minat Wisatawan). Skripsi. Surakarta: Universitas Sebelas Maret. 